\title{
CSR reporting on apparel companies' websites: framing good deeds and clarifying missteps
}

\author{
Jamie Gaskill-Fox, Karen H Hyllegard ${ }^{*}$ and Jennifer Paff Ogle
}

\author{
* Correspondence: \\ karen.hyllegard@colostate.edu \\ Department of Design and \\ Merchandising, Colorado State \\ University, 150 Aylesworth SE, Fort \\ Collins, CO 80523-1574, USA
}

\section{Introduction}

Corporate social responsibility (CSR) reporting refers to the means by which an organization communicates to its stakeholders about the social, environmental, and financial impacts that its business practices have on society (Gray, 2008). CSR reporting is founded in the belief that organizations have responsibilities toward society that go beyond their legal obligations and economic interests (Carroll, 1991), including responsibilities toward employees, customers, suppliers, government and non-government organizations (Fraser, 2005). Within the global textiles and apparel industry, CSR involves mindful consideration of how the design, development, production, distribution, marketing, and consumption of goods may impact multiple stakeholders and simultaneously generate profit for individual companies (Dickson \& Eckman, 2006). As such, disclosures of CSR business practices within the textiles and apparel industry necessarily focus upon a broad range of issues, including the environment, labor, fair trade, consumer deception and safety, and the objectification and commodification of the human body (e.g., in the context of advertising).

Companies that engage in CSR reporting may derive varied benefits, including the ability to hire and retain quality employees (Dawkins, 2004), build customer loyalty (Sen \& Bhattacharya, 2001), build/manage brand image (Kavitha \& Anita, 2011; Welford \& Frost, 2006), minimize/manage risks throughout the supply chain (Welford \& Frost, 2006), and increase long-term profitability (Vanhamme \& Grobben, 2009). Companies disclose information about their CSR business practices through advertising and public relations to foster awareness of their socially responsible decisionmaking among stakeholders (Capriotti \& Moreno, 2007; Farache \& Perks, 2010). Research also suggests that stakeholders are interested in being informed about companies' CSR initiatives (Dawkins \& Lewis, 2003) and are willing to support companies that embrace socially responsible practices and to rebuke companies that act irresponsibly (Consumers Worldwide 1999).

Although annual reports are a primary channel for disclosing CSR practices (Kavitha \& Anita, 2011), company websites also are used to communicate about CSR practices, especially among larger companies (Holder-Webb, Cohen, Nath, \& Wood, 2009) because the internet provides a practical and inexpensive way by which to share a wealth of information with a variety of stakeholders (Kent, Taylor, \& White, 2003). Further, websites offer an advantage over conventional mass media in that they provide a means by which to obtain direct feedback from stakeholders (Pollach, 2005). 
Prior studies have examined how companies use their websites to communicate about their CSR initiatives, including the types of information presented, the stakeholders to whom this information is targeted, and the factors that influence the type and amount of disclosures made (e.g., Basil \& Erlandson, 2008; Capriotti \& Moreno, 2007; Holder-Webb et al., 2009). No studies to date, however, have focused specifically upon CSR reporting among apparel companies via company-owned websites. This is somewhat surprising, given that the apparel industry poses a high risk for negative social and environmental impacts. In fact, over the past few decades, the apparel industry has received considerable criticism for numerous ethical "missteps", thereby prompting the companies and their stakeholders to develop new CSR initiatives and to report their engagement in such initiatives. These initiatives reflect growing momentum within the apparel industry toward increased social responsibility, prompting an industry-wide increase in voluntary measures (e.g., codes of conduct) as well as tighter regulatory requirements (see Young \& Marais, 2012) and more encompassing industry collaborations such as the Clean Clothes Campaign, Worldwide Responsible Accredited Production, and the Sustainable Apparel Coalition. Taken together, these developments warrant an examination of the content of apparel companies' communications about their socially-responsible initiatives, particularly given that effective communication of CSR initiatives to stakeholders is critical if companies wish to achieve maximum return on their CSR investment (Basil \& Erlandson, 2008).

Thus, the purpose of this interpretive study was to gain understanding of apparel companies' reporting about CSR policies and practices and how CSR reporting among apparel companies has evolved over time. Specifically, this study examined the corporate websites of three apparel companies, exploring the companies' stated motives for engaging in CSR, the themes present in their CSR disclosures, and the stakeholder groups identified in these disclosures. An examination of CSR disclosures within the apparel industry is important because "individual industries operate within distinctively different contexts and with dissimilar social and environmental concerns, and patterns of stakeholder involvement and activism" (Griffin \& Mahon, 1997, p. 25). As one of the most global industries in the world, apparel companies operate in a complex multinational context with varied degrees of government involvement, employment regulation, and environmental protection, and as such, these companies must assume primary responsibility for a multitude of legal and moral standards, which may include communications about their CSR practices (Laudal, 2010). Further, because the apparel industry is highly competitive, to the point that consumers often do not differentiate among companies' products, CSR practices and disclosures may play a significant role in shaping consumer behavior (Bhattacharya \& Sen, 2004). As such, this analysis offers insight into the way in which apparel companies frame their business activities, and in particular, their engagement in CSR business practices, providing a view of the impressions that such companies may wish to foster in the eyes of stakeholders.

\section{Review of literature}

\section{CSR Reporting on corporate websites}

Prior work examining CSR reporting on corporate websites has focused primarily upon the factors that motivate CSR reporting, the specific topics or themes addressed in CSR 
reporting, and the stakeholders addressed within the CSR disclosures. In an early content analysis of CSR reporting on websites among U.S. and European companies, Maignan and Ralston (2002) conceptualized CSR as comprising three aspects: motivating principles, processes, and stakeholder issues. Motivating principles were categorized as value-driven, stakeholder-driven, and performance-driven. Processes were defined as those activities undertaken by companies to realize CSR goals through the development or implementation of policies, practices, or programs (Maignan \& Ralston, 2002). Examples of CSR processes identified included volunteerism, codes of conduct, and health and safety programs. Stakeholder issues were conceptualized in relation to topics of potential interest to those impacted by company decisions. The researchers identified five stakeholder groups targeted by the companies (community, customers, employees, shareholders, and suppliers) and a number of issues that were addressed for each group (e.g., quality for customers; equal opportunity for employees).

In an investigation of CSR reporting on corporate websites among Spanish companies, Capriotti and Moreno (2007) identified ten topic areas related to CSR - corporate profile, corporate governance, products and services, employment and human resources, social action, environmental action, external criteria, relationship with publics, economic action, and corporate ethics. Findings revealed that the companies focused primarily upon a limited number of issues in their CSR reporting, including social action (e.g., external corporate philanthropy, funding/sponsorship of cultural events or organizations) and environmental action.

In a content analysis of the corporate websites of U.S. firms representing diverse business sectors, Holder-Webb et al. (2009) found that CSR reporting most frequently involved the disclosure of information related to community matters, health and safety, diversity and human resources, environmental issues, and human rights and supply chain practices. In general, disclosures were judged to be positive in tone; providing support for the researchers' proposition that CSR disclosures may assist marketing efforts. The researchers also discovered differences in CRS reporting across industries (pharmaceuticals, grocery, surgical equipment, software, and oil) in regard to the frequency and intensity of disclosures as well as the choice of disclosure format.

Researchers also have explored how companies' website communications about CSR have changed over time. Basil and Erlandson (2008) discovered that in 2003, only 27\% of the Canadian companies in their sample used their websites to express their engagement in CSR, whereas by $2006,67 \%$ of the companies did so. The researchers also observed a shift in the content of the companies' CSR reporting, moving from an emphasis upon issues of philanthropy to topics of environment, health/safety, and codes of ethics (Basil \& Erlandson, 2008).

Additionally, researchers have identified stakeholders who are often targeted in CSR reporting, including customers, employees, shareholders, suppliers, competitors, and society (Capriotti \& Moreno, 2007; Maignan \& Ralston, 2002; Snider, Hill, \& Martin 2003). Capriotti and Moreno (2007) found that few companies explicitly mentioned stakeholders within website communications, but those that did focused on employees, investors/ shareholders, consumers, and the community. In Snider et al.'s (2003) analysis, "targeted" stakeholder groups were identified based upon the type of CSR information and activities noted. For example, website communications referencing workforce diversity were interpreted as directed toward employees. 


\section{CSR Reporting in the textiles and apparel industry}

To date, few studies have addressed CSR reporting among companies operating in the global apparel industry, and the identified studies have focused solely upon human rights issues. In one such study, Ählström (2010) analyzed H\&M's response to the challenge from civil society organizations to create responsible discourse around the safeguarding of workers engaged in outsourced apparel production. Findings revealed that H\&M previously addressed working conditions/workers' rights in its contracts with suppliers, but it was not until 1998, when the company was faced with growing pressures from civil society organizations and negative media attention, that the company made its code of conduct public, which was several years after the implementation and disclosure of codes of conduct by the largest U.S. apparel companies (Ählström, 2010). Earlier research (e.g., Emmelhainz \& Adams, 1999; Kolk \& van Tulder, 2002) revealed that a growing number of apparel companies established codes of conduct during the 1990s in order to ensure healthy and safe working conditions and to mitigate labor abuses, such as child labor. The research also revealed that such codes tended to be vague in regard to monitoring and enforcing compliance and did not address broader social initiatives, such as education for children.

Islam and Deegan (2010) examined the relationship between negative media attention and CSR disclosures by two global apparel companies, Nike and H\&M, by reviewing the companies' annual reports. The researchers considered six general themes of CSR disclosure-environment, energy, human resources, product, community and otherand discovered strong correlations between the issues that generated the most negative media attention and the disclosures made by the apparel companies. Findings demonstrated strong positive correlations between negative media attention and disclosures related to labor practices in developing countries by both Nike and H\&M, and strong positive correlations between negative media attention and disclosures related to the environment for $\mathrm{H} \& \mathrm{M}$, only.

In their study of CSR reporting among global clothing companies, Islam and McPhail (2011) examined the extent to which companies addressed the issue of human rightsspecifically the adoption of the International Labor Organization's (ILO) workplace human rights standards-in their annual reports, stand-alone SR reports, and SR codes of conduct from 1990 to 2007. Findings revealed that disclosures on human rights increased considerably after 1998-the year in which the ILO's standards were accepted by the global community.

\section{Institutional theory \& stakeholder theory}

This study was informed by two theories of organizational behavior-institutional theory and stakeholder theory. Institutional theory posits that an organization must conform to the rules and belief systems that serve as the authoritative guidelines for social behavior in a given field in order to earn legitimacy (DiMaggio \& Powell, 1983; Meyer \& Rowan, 1977; Scott, 2004, 2005). Scott (2005) asserts that institutions are comprised of regulative (laws, regulations), normative (social prescriptions and obligations), and cultural-cognitive (shared cultural meanings or understanding) elements and that "all three elements are at work, albeit in varying ways, to stabilize social behavior" (p. 10) and the elements "may not be aligned, and one may undermine the effects of the other" (p. 11). Further, the dominance of any one element may vary across institutions as well as within institutions over time (Scott, 2005). Thus, organizations may engage in social 
behaviors, including CSR initiatives and reporting, for a variety of reasons, irrespective of their ethical beliefs (Holder-Webb et al., 2009). For instance, organizations may perceive that CSR initiatives are needed to establish competitive position as well as legitimacy. Further, institutional theory proposes selective disclosure of information that directs attention toward positive (and away from negative) behaviors and outcomes (Elsbach \& Sutton, 1992; Meyer \& Rowan, 1977).

Stakeholder theory posits that an organization has obligations toward multiple individuals or groups who can affect, or be affected by, the organization's decision-making processes (Freeman, 1984). Stakeholder theory demands that consideration be given to stakeholders' concerns throughout the decision-making process. Halal (2001) argued that collaborative problem-solving approaches represent the most powerful strategy for establishing stakeholder engagement and, in turn, meeting organizational goals. With increasingly diverse groups of stakeholders to consider, companies face the challenge of determining which of the often conflicting stakeholder needs they should address. Hart and Sharma (2004) addressed the importance of proactively seeking out "fringe" [i.e., secondary] stakeholders to build goodwill and minimize the likelihood of organized responses (e.g., boycotts and negative publicity) to adverse business situations. According to Hart and Sharma (2004), engaging fringe stakeholders allows companies to identify innovative ideas that will ultimately make them more competitive.

Institutional theory and stakeholder theory provide the foundation for this study by offering a lens through which to explore the various reasons why companies engage in CSR practices (i.e., how regulative, normative, and cultural-cognitive elements stabilize social behavior), the content of their CSR reporting, and the diverse groups (i.e., stakeholders) that may shape these practices. As such, this research sought to answer four questions: What themes can be identified in the CSR reporting by apparel companies? How do these themes vary across apparel companies? What stakeholder groups are addressed in the apparel companies' CSR reporting? How has the content of apparel companies' CSR reporting changed over time?

\section{Method}

To meet the aims of this study, the corporate (i.e., nonretail) websites of three apparel companies were analyzed for content related to CSR (i.e., examples of CSR reporting). As noted, such an analysis can provide insights into how companies communicate with various stakeholders to convey the notion that they are "doing the right thing" (cf., Welford \& Frost, 2006). Because such an analysis focuses upon self-reporting, however, it represents a company perspective and a particular version of reality that may not fully reflect actual events or coincide with third-party interpretations of company decisions and practices.

Purposive sampling was used to identify three U.S. apparel companies recognized as innovators and leaders in CSR: Gap, Inc., Levi Strauss and Co., and Nike (Freeman, 2006; Kolk \& van Tulder, 2002). It is important to note that, in the past, each of these companies has experienced negative publicity owing to ethical transgressions in their business decisions and practices (e.g., labor abuses). For instance, in 1999, Gap, Inc. received negative publicity when it was one of 26 apparel companies named in the Saipan Lawsuit that alleged illegal labor practices and breaches of human rights in apparel factories (Iwanow, McEachern, \& Jeffrey, 2005). Similarly, Levi Strauss was the subject of scrutiny when, in 1994, female employees walked off the job in Indonesian factories 
where Levis and Dockers were being manufactured over treatment by factory managers who were accused of being abusive and refusing to pay minimum wage (Greider, 1994). And, in 1997, the New York Times disclosed that a Vietnamese factory manufacturing products for Nike exposed workers to unacceptable levels of toxic chemicals and sweatshop conditions (i.e., excessive working hours) (Parloff, 2002). In turn, the publicity these companies received as a result of these transgressions has moved them to reform their practices and, in so doing, to establish their reputations as leaders in CSR within the apparel industry (e.g., Zadek, 2004). Gap, Inc., Levi Strauss and Co., and Nike also were selected because they are engaged in global apparel sourcing and production, a high risk industry for negative social and environmental impacts, and because they maintain corporate websites that are used to report CSR policies and practices.

To explore how CSR reporting on these companies' websites has changed over time (cf. Basil \& Erlandson, 2008), the information provided on companies' websites from 2001 was compared to that provided on the websites from 2009. The year 2001 was chosen because it was the earliest year for which comprehensive website archive data were available for all three companies. The year 2009 was selected because it was the year in which data were collected. To provide context for the interpretation of the data, it is important to consider various economic, political, and social influences upon general business operations as well as specific industry conditions during these years. For instance, it is likely that business practices were impacted by a global economic slowdown in 2001 and an economic recession in the United States in 2008-2009. Similarly, emphasis on labor issues and sweatshop production in the late 1990s and early 2000s and the environment in the later 2000s likely shaped businesses' CSR initiatives during the time periods of interest.

\section{Data collection}

The sample included all CSR content (i.e., text) reported on the companies' websites, excluding information in the form of PDF files, videos, and links to external sites. For the purpose of this analysis, "CSR content" was conceptualized following prior analyses of website-based communications about CSR (Capriotti \& Moreno, 2007; Maignan \& Ralston, 2002). Specifically, content related to the following topics was identified for inclusion in the sample: codes of conduct, corporate social responsibility, diversity/equal opportunity, education, employee development, the environment, ethics/ethical practices, labor issues/practices, philanthropy, quality of life, social responsibility, stakeholders, transparency, values, and volunteerism. Snider et al.s (2003) approach was adopted to identify targeted stakeholder groups. That is, "targeted" stakeholder groups were identified based upon specific reference to the type of CSR information and activities noted.

The companies' 2001 websites were examined for CSR content using the Wayback Machine, an archival, electronic database of webpages that represents a collaborative effort between The Library of Congress and The Smithsonian ("Web Collaborations," n.d.). In order to minimize the possibility that changes to the website content would be made during the data collection period, data from each company's 2009 website were captured within 24-72 hours.

\section{Data analysis}

Constant comparison (Corbin \& Strauss, 2008) processes were used to analyze the data for emergent themes related to CSR. During open coding, the data were broken into 
individual words, phrases, or sentences that conveyed key meanings or ideas. Next, these meanings were compared and contrasted to establish categories and subcategories of meaning (e.g., labor practices, philanthropy), which formed the basis for the development of a coding guide that was applied to the data (Corbin \& Strauss, 2008). Open coding was followed by axial coding, during which possible relationships between categories and subcategories were identified.

Several measures were taken to increase the dependability of data collection and analysis. First, interpretations of the data were negotiated among the researchers to ensure accuracy of the data collection and analysis. Second, an audit coder verified both sampling and coding decisions. The inter-rater reliability coefficients for the data selection and coding were $92.2 \%$ and $95.8 \%$, respectively. Based upon the high level of agreement, the auditing process was suspended after $15 \%$ of the decisions had been checked. Disagreements in decision-making were negotiated.

\section{Results}

CSR reporting on the corporate websites of the Gap, Levi Strauss, and Nike addressed the apparel companies' motivations for engaging in CSR as well as six major themes: philanthropy, labor practices, environmental practices, diversity, accountability, and recognition of CSR efforts. Three themes - philanthropy, labor practices, and environmental practices - represent conceptual overlap with those identified by Capriotti and Moreno (2007). The present analysis also revealed commonalities and differences in the emphasis the companies gave to the themes identified. Further, analyses indicated that Gap, Levi Strauss, and Nike considered themselves to be accountable to multiple stakeholders through their CSR initiatives. Commonly noted stakeholders included activists, auditors, charitable organizations, communities, competitors, consumers, employees, (natural) environment, factory workers, governments, media, nongovernment organizations, and underrepresented groups. Shareholders, however, were rarely mentioned explicitly in relation to the companies' CSR policies and practices, although a commonly cited rival model to stakeholder theory suggests that companies should first support the interests of shareholders (Donaldson \& Preston, 1995). The motives, themes, and the stakeholders identified in CSR reporting by the apparel companies are discussed below.

\section{Motivations for engaging in CSR}

Gap, Levi Strauss, and Nike reported their motivations for engaging in CSR within the content of their corporate websites. Content related to motivations aligned closely with the three motivations for CSR engagement identified by Maignan and Ralston (2002): performance-driven, value-driven, and stakeholder-driven. In the present analysis, performance-driven motivations included references to competitive, financial, and innovation advantages. All three companies framed their socially responsible approach to business as a competitive advantage, as reflected in Nike's efforts to foster employee diversity:

Nike's corporate culture supports diversity of all kinds, and...vehemently protects and values differences among all our teammates... It is one of our strongest competitive advantages (Nike Helps, 2000, para. 1). 
Although positioning CSR as a competitive advantage might be interpreted as selfserving, Nike framed the recruitment of a diverse workforce as essential to communitybuilding, which in turn, allowed the company to better meet the needs of consumers. All three companies also implied that CSR could increase profits and enhance their abilities to meet stakeholder expectations, as is demonstrated from this 2009 excerpt from Gap's website:

Whether we're saving costs by reducing energy consumption or creating covetable products through innovative, sustainable design, we believe that reducing our impact on the environment can also result in positive business benefits ("Caring for," n.d., para. 2).

Additionally, each of the companies framed CSR as an essential component of its corporate identity. For example, on its 2001 website Nike described its commitment to philanthropy as "part of who we are" (Mission and Overview, n.d., para. 1), and on its 2009 website Gap, Inc. described social responsibility as, "fundamental to who we are and how we operate as a company" (At Gap Inc., n.d., para. 1). The integration of CSR into company culture also was demonstrated on Nike's 2009 website which stated, "Nike's long-term corporate responsibility goals are broadly embedded into our business" (Nike Responsibility FY05-06 CR Report, n.d.). In this quote, Nike suggested that the company considered CSR in every aspect of its business. And, a passage from Levi Strauss \& Co.'s 2009 website demonstrated how CSR was an extension of its identity:

Our corporate values - Empathy, Originality, Integrity and Courage - are the foundation of our company and define who we are. They underlie how we compete in the marketplace and how we behave as a corporate citizen. They guide our foundations' giving programs, the support we provide to communities where we have a business presence, our employee community programs and our approach to responsible product sourcing (Our Corporate Value, n.d.).

In this quote, Levi Strauss \& Co. gave the impression that CSR was intrinsic to its identity because the company operated from a foundation of core values that drove it to act ethically. It also suggested that Levi Strauss \& Co.'s CSR programs were created as a result of its values-based approach to business.

Stakeholder-driven motivations for CSR were presented as a response to legal or policy requirements or as a reaction to stakeholder influences. For instance, on its 2001 website, Nike focused on factory workers when it described its efforts to meet local expectations for fair pay by establishing "the cash wage for entry level workers using standards set by local governments or trade unions in each country" ("Labor: Frequently," n.d., para.3). In so doing, Nike demonstrated how it was "[performing] in a manner that [was] consistent with the expectations of government and law," which Carroll identified as an obligation of a socially responsible company (1991, p. 40). By emphasizing its engagement with stakeholders, including governments and trade unions, Nike constructed itself as sensitive to the cultures in which it operated. Website content also suggested that the apparel companies sometimes developed specific CSR initiatives in response to stakeholder pressures. For example, on its 2001 website, Gap stated that it was working to resolve "manufacturing-related concerns, including those raised by interested parties such as customers, 
religious groups, government, non-government, and human rights groups" ("Saipan," n.d., para.1). Although this content was clearly reactionary in nature, it also illustrates Gap's awareness of the need to consider the needs of diverse stakeholders, including fringe groups, in an attempt to engender goodwill and minimize the likelihood of organized responses to unpopular business decisions (Hart \& Sharma, 2004).

\section{Themes and Stakeholders Identified within CSR Reporting \\ Philanthropy}

The importance of philanthropy to each of the companies was evident in how they framed their practice of giving as integral to their corporate cultures, histories, and identities. Reporting about philanthropic involvement encompassed two sub-themes: employee involvement in communities and helping people help themselves.

The companies framed employee involvement in philanthropic endeavors as beneficial to the direct recipients of the philanthropy, local communities, employees, and the companies, frequently highlighting the various monetary, in-kind, and/or volunteer contributions provided by the companies and their employees. Consistent with institutional theory and the tenet that organizations may engage in disclosure of information that elicits attention for their good deeds, the companies also noted how participation in community involvement programs improved their reputations among stakeholders. For example, on its 2009 website Gap noted,

Not only can our [community investment] work help build stronger communities, it engages our employees, and attracts both consumers and investors ("Community Investment," n.d., para. 3).

As the following passage from Levi Strauss's 2001 website demonstrates, the companies also framed philanthropy as a way to "help people help themselves," that is, to educate and empower community members to create lasting change through their own efforts:

Local communities all over the world face some tough problems. We help them create their own solutions. Levi Strauss and the Levi Strauss Foundation act as catalysts for positive change in our communities by awarding grants, encouraging employees to volunteer their time and standing behind critical, controversial issues. (“Giving Programs," n.d., para.1).

Likewise, on its 2009 website, Gap described the company's view on the importance of educating women in developing countries, effectively communicating a commitment to empowering others to improve the quality of their lives:

We believe that access to education is crucial in giving women the chance to change their lives...offering education and life skills training in such critical areas as health care and legal rights, as well as leadership and job training so that women can move into management positions ("Women in the," n.d., para. 2-4).

This effort on the part of Gap represents a proactive approach to fostering professional development among uneducated women, who have historically represented a fringe group in the apparel industry (cf., Hart \& Sharma, 2004). 


\section{Labor practices}

Companies' CSR reporting on labor practices revolved around three subthemes: transparency, partnerships and collaboration, and benefits and challenges. That reports addressing transparency were identified on all three websites suggests that the companies perceived a need to be forthcoming with stakeholders about their labor practices and is consistent with findings from other analyses of CSR reporting among apparel companies (Ählström, 2010; Islam \& Deegan, 2010). Further, this finding supports the proposition that organizations often conform to institutional norms to earn legitimacy in their respective fields (DiMaggio \& Powell, 1983; Meyer \& Rowan, 1977; Scott, 2004). In this vein, Nike's 2001 website included a section titled "Transparency 101" that was designed to disclose information about the labor conditions in factories where Nike's products were manufactured. The company also included articles written by thirdparty media organizations about the "Transparency 101" initiative, perhaps adding to the credibility of the company's efforts; consumers tend to view third-party messages (e.g., news stories) as more credible than messages created by the companies themselves (Calabro, 2003).

Factory monitoring and compliance policies and procedures, including roles of factory assessors and actions taken if violations occurred, also were presented on the companies' websites. With the exception of Gap, the companies disclosed the names and locations of the factories where their products were manufactured. In some cases, this information was provided in response to stakeholder demand, such as Nike's 2001 disclosure of the names and locations of factories where its university-affiliated products were manufactured.

Gap and Nike also reported stakeholder criticisms of their labor practices. For example, in 2001 Nike addressed stakeholder criticisms regarding labor practices, in some cases clarifying and defending company actions and in some cases apologizing and describing efforts to rectify its trespasses. To this end, the company published letters written by stakeholders, included news stories and editorials by third-parties that criticized the company's practices, and described protests by activist groups. Nike also published company responses to the criticisms, perhaps as a way to manage the company reputation by influencing stakeholder evaluations of the company.

Further, as demonstrated on Gap's 2009 website, the companies advocated for industry-wide collaboration as a means by which to enact change in labor practices:

We believe that greater industry collaboration is one of the most effective ways to bring meaningful, lasting change in garment factories ("Frequently Asked," n.d., para. 44).

This statement speaks to the value of partnering with stakeholders to address complex issues and is consistent with Halal's (2001) proposition that cooperative problemsolving can foster positive social and economic outcomes.

All three companies discussed the benefits of their labor policies, including improved working conditions, education for workers, health care for workers, fair wages, decreased child labor, improved productivity, improved environmental conditions, and improved economies. Factory managers, workers, and communities were framed as the major beneficiaries in these communications. Further, company websites presented information regarding the challenges associated with implementing labor standards, such 
as cultural differences, the lack of internationally accepted labor standards, and the lack of factory managers' willingness to enforce standards and/or to provide transparency. The following example from Gap's 2009 website illustrates company efforts to overcome such challenges:

One of the biggest challenges is dealing with factory management that [is] not transparent with us. They show us fake documents, tell workers what to say and try to manage our audit...We conduct surprise audits at factories and get the real records before they can be hidden away. We conduct off-site interviews with workers so that they are not under any pressure from factory management. After collecting the facts we confront management and stress how important it is that they be transparent with us. ("Global Compliance," n.d., para. 3).

\section{Environmental practices}

Consistent with work exploring CSR reporting on corporate websites (Capriotti \& Moreno, 2007; Islam \& Deegan, 2010; Maignan \& Ralston, 2002), Gap, Levi Strauss, and Nike addressed concerns for the natural environment (e.g., through the provision of environmental mission statements) and/or actions to reduce negative environmental impacts. Content related to environmental impacts focused on three subthemes: the product lifecycle, employee involvement, and benefits.

Discussions on the topic of product lifecycle focused upon design, materials selection, production processes, and end of life, but rarely addressed distribution or consumer care and product maintenance (Brown \& Wilmanns, 1997). Both Gap and Nike discussed product design in relation to their efforts to manage environmental impacts. For instance, in 2009, Nike highlighted its sustainable design ethos, "Considered Design," and noted the influence of its designers on various phases of the product lifecycle:

Considered [Design] challenges designers to use environmentally preferred materials, reduce waste, create sustainable manufacturing processes and use innovation to reduce our overall impact ("Nike Talks," n.d., para. 9).

Consistent with research on raw materials selection (e.g., Chen \& Burns, 2006; Dickson, Loker, \& Eckman, 2008), all three companies demonstrated awareness and understanding of the fact that fiber and textile choice may have environmental impacts. As such, the companies discussed their use of organic cotton, polyester made from recycled plastics, and materials made from other recycled or reclaimed products in the development of new products. Additionally, the companies spoke to their efforts to minimize the environmental impacts of production processes through the implementation of standards and regulations for factories as well as their efforts to eliminate the use of harmful substances in the manufacturing process. Nike was the only company to emphasize end-of-life product management on both its 2001 and 2009 websites. In 2009, the company discussed its Reuse-A-Shoe program - through which athletic shoes of any brand are collected, separated into parts, and ground into a substance known as "Nike Grind" to make new products and sports surfaces (e.g., basketball courts, playgrounds) (Steve Nash, 2008) - thus preventing worn shoes from being discarded in landfills. 
Each company identified employee involvement as essential for creating innovative solutions to environmental issues. To this end, companies discussed efforts to provide employee training on sustainability issues, offer incentives for participation in environmental programs, organize volunteer opportunities, implement recycling programs at company facilities, and require understanding of sustainability among new hires.

The companies also reported efforts to reduce negative impacts on the environment as beneficial for both society and their bottom lines, as illustrated in the following 2001 quote:

Not only will these extra [energy-saving] efforts pay off with a healthier environment, but also with Nike's bottom line. Energy saving design features will result in an annual savings of 2,048,628 $\mathrm{kWh} / \mathrm{yr}$ and 2270 therms of natural gas consumption. That adds up to $\$ 103,113$ in energy savings per year. ("Where We Work," n.d., para. 4).

Further, the companies characterized environmental programs as beneficial to employees and factory workers. For example, on its 2009 website Gap described its provision of preferential parking spaces for carpoolers and cyclists as benefits for employees. Additionally, companies addressed how efforts to improve indoor air quality in factories and to reduce the environmental impacts of laundries enhanced conditions for factory workers.

\section{Diversity}

Gap, Levi Strauss, and Nike addressed diversity within their CSR reporting, with discussions focusing upon two subthemes: efforts to foster diversity and benefits of diversity. In conceptualizing diversity, both Gap and Levi Strauss underscored recognizing consumers' ethnic, cultural, and lifestyle differences as a means of providing optimal service. By comparison, Nike described diversity not in terms of difference, but in terms of its potential to "elevate" the company to greater success.

All three companies discussed efforts to foster diversity among stakeholders, including employees, suppliers, and consumers. For instance, the companies addressed equal opportunity employment policies as well as internal programs created to promote appreciation for differences among employees. And, on its 2001 website, Nike provided justification for encouraging business relationships with minority and women-owned suppliers:

We encourage partnerships with minority and women-owned enterprises and understand the importance of building stronger ties in our communities...These demographics present a real opportunity for Nike to implement strategies that will impact the quality of our future. Minority and women-owned businesses are important to... the economic viability of the communities in which they operate. Building longrange strategic partnerships to diversify our company's supplier base is critical to sustaining long-term growth. ("Our Supplier," n.d., para. 1).

The companies also reported on their efforts to appeal to diverse consumers through their marketing practices. On its 2009 website, Nike featured information about its Air Native N7 shoe designed to address the unique fit and width requirements of the 
Native American foot. In referencing the needs of a minority group, Nike demonstrated a proactive approach to considering fringe groups in their product development process (cf., Hart \& Sharma, 2004). Additionally, company dialogue about diversity included reference to corporate actions discouraging discrimination against consumers, such as Gap's claim to treat customers with integrity and respect, regardless of physical appearance or other differences.

All three companies positioned their efforts to foster diversity as beneficial to company growth and reputation. Nike, however, took a unique approach to conveying these benefits of diversity, by surveying employees worldwide about the meaning of diversity. Based on the employee input, Nike also developed a diversity vision that read, "Nike's vision is for every team to be high-performing, diverse and inclusive" (Diversity and Inclusion, Overview, n.d., para. 1). Nike's involvement of employees in defining diversity and in creating its diversity vision represented the company's commitment to being inclusive and also illustrated how it engaged stakeholders in shaping its CSR programs.

\section{Accountability}

Reports of accountability - which may demonstrate a company's level of commitment to CSR (Clarkson, 1995) - addressed two subthemes: CSR results and checks and balances for CSR practices. When reporting the results of their CSR initiatives, Gap, Levi Strauss, and Nike highlighted the positive outcomes that accrued from the implementation of these initiatives, which provides support for institutional theory and the attendant premise that organizations may be inclined to direct attention toward positive behaviors and outcomes (Elsbach \& Sutton, 1992; Meyer \& Rowan, 1977). For example, on its 2001 website, Nike published an article outlining the company's progress toward meeting its goals for manufacturing practices, including minimum age limits for factory workers, indoor air quality in factories, and labor conditions ("A Glance," n.d.). Including this dedicated article on the company website may have enhanced Nike's credibility as per its efforts to improve its manufacturing practices. In reporting the results of their CSR initiatives, the companies also noted challenges encountered. On its 2001 website, Nike specifically spoke to the difficulties it confronted when attempting to increase the minimum age requirement for factory workers in other countries, including the forgery of age verification documents ("A Glance," n.d.). Acknowledging such challenges likely highlighted for stakeholders the complexity of implementing successful CSR initiatives, perhaps constructing an impression of credibility within stakeholders' eyes (DiMaggio \& Powell, 1983; Meyer \& Rowan, 1977; Scott, 2004).

Companies also discussed accountability in terms of the checks and balances developed to ensure that CSR practices were in line with company goals and stakeholder expectations. Checks and balances included third party evaluations of CSR practices, hotlines for stakeholders to report violations of codes of conduct, efforts of activist groups to influence company actions, and internal policies or structures designed to support CSR initiatives. The value of third-party evaluations, is reflected in the following excerpt from Gap's 2009 website:

External organizations challenge us with different goals, identify new or different ways in which we can enhance our program, and hold us accountable for results (“External Evaluations," n.d., para.1). 
Gap also described findings from evaluations of its SR programs by Social Accountability International and Verité, including praise for their efforts and suggestions for improvements. Because the evaluations were conducted by outside organizations, the results may have appeared to be more objective to stakeholders, thus adding to the credibility of Gap's reporting.

\section{Recognition of CSR}

The companies also addressed third-party recognition of their CSR efforts, which has not been previously identified as a theme within the literature on CSR reporting. Presenting such recognitions likely constructed Gap, Levi Strauss, and Nike as leaders in terms of social responsibility, allowing them to positively position themselves by alerting stakeholders to their accomplishments in the arena of CSR (Elsbach \& Sutton, 1992; Meyer \& Rowan, 1977). For example, on its 2009 website, Gap explained how it earned top ratings for its business practices from Ethisphere Magazine ("Ethisphere," n.d., para.1):

Gap was chosen by Ethisphere Magazine as one of the World's Most Ethical Companies in recognition of [its] commitment to ethical leadership and corporate SR. Thousands of companies were examined and less than 100 were selected. In addition, the Ethisphere Council gave Gap's Code of Business Conduct an 'A' grade the only retail company to receive this grade. ("Recognition," n.d., para. 9).

Likewise, Levi Strauss's 2001 website positioned the company as a leader in CSR by describing recognition for its efforts to educate workers about AIDS:

Levi Strauss has played a leadership role in educational programs and policies regarding AIDS in the workplace. The company has received numerous awards and recognitions for its efforts to combat the HIV epidemic. In 1997 it received the first National Business and Labor Award for Leadership on HIV/AIDS from the United States Centers for Disease Control. (“Business Operations," n.d., para. 5).

Levi Strauss also included third-party acknowledgements for its HIV/AIDS education efforts on its 2009 website, noting its recognition by the San Francisco AIDS Foundation for more than 25 years of commitment to the fight against HIV/AIDS. This recognition may have helped to convey the company's commitment to the cause as genuine because it highlighted the length of time the company had been involved in the search for a cure for HIV/AIDS.

\section{Evolution in CSR Reporting: Comparing 2001 and 2009}

Following Basil and Erlandson (2008), the present analysis included a longitudinal component, exploring the evolution of CSR reporting. Changes in CSR reporting on corporate websites among Gap, Levi Strauss, and Nike are presented in Table 1. This table summarizes each company's reporting in relation to motivations for engagement in CSR and to each of the six emergent themes for both 2001 and 2009, facilitating comparisons across time and company.

In general, the companies provided more information and greater detail about their CSR practices in 2009 than they did in 2001. Nike, however, was an exception to this 
Table 1 Summary and comparison of companies' website communications related to CSR, 2001-2009

\begin{tabular}{|c|c|c|c|c|c|c|}
\hline \multirow[b]{2}{*}{ Theme } & \multicolumn{2}{|l|}{ Gap, Inc. } & \multicolumn{2}{|l|}{ Levi Strauss and Co. } & \multicolumn{2}{|l|}{ Nike } \\
\hline & 2001 & 2009 & 2001 & 2009 & 2001 & 2009 \\
\hline \multirow{7}{*}{$\begin{array}{l}\text { Motivations } \\
\text { for CSR }\end{array}$} & - Financial advantage & - Financial advantage & - Overall values & - Competitive advantage & - Competitive advantage & - Competitive advantage \\
\hline & - Overall values & - Drives innovation & - Company history & - Financial advantage & - Financial advantage & - Financial advantage \\
\hline & & & & - Drives innovation & - Drives innovation & \\
\hline & - Company history & - Overall values & & - Overall values & - Overall values & - Drives innovation \\
\hline & & - Company history & & - Company history & - Legal/regulatory compliance & - Overall values \\
\hline & & $\begin{array}{l}\text { - Legal/regulatory } \\
\text { compliance }\end{array}$ & & - Legal/regulatory compliance & & - Company history \\
\hline & & - Stakeholder influences & & - Stakeholder influences & - Stakeholder influences & - Stakeholder influences \\
\hline \multirow[t]{5}{*}{ Philanthropy } & $\begin{array}{l}\text { - Youth, HIV/AIDS } \\
\text { - Employee contribution } \\
\text { matching and volunteer } \\
\text { programs }\end{array}$ & $\begin{array}{l}\text { - Youth, women, } \\
\text { HIV/AIDS, factory } \\
\text { workers, communities }\end{array}$ & $\begin{array}{l}\text { - Youth, HIV/AIDS, } \\
\text { underserved populations, } \\
\text { anti-racism }\end{array}$ & $\begin{array}{l}\text { - Youth, HIV/AIDS, } \\
\text { underserved populations, } \\
\text { women, girls, environment, } \\
\text { employees, disaster victims, } \\
\text { factory workers }\end{array}$ & $\begin{array}{l}\text { - Youth, women, communities, } \\
\text { environment, disaster victims }\end{array}$ & $\begin{array}{l}\text { - Youth, women, girls, } \\
\text { communities, environment, } \\
\text { HIV/AIDS, disaster victims, } \\
\text { underserved populations, } \\
\text { schools }\end{array}$ \\
\hline & & $\begin{array}{l}\text { Employee contribution } \\
\text { matching and volunteer } \\
\text { programs }\end{array}$ & $\begin{array}{l}\text { Employee contribution } \\
\text { matching and volunteer } \\
\text { programs }\end{array}$ & - Philanthropy case studies & $\begin{array}{l}\text { Employee contribution } \\
\text { matching and volunteer } \\
\text { programs }\end{array}$ & $\begin{array}{l}\text { Employee contribution } \\
\text { matching and volunteer } \\
\text { programs }\end{array}$ \\
\hline & & $\begin{array}{l}\text { Personal stories from } \\
\text { employee volunteer } \\
\text { efforts }\end{array}$ & - Philanthropy case studies & - Disclose grants lists & $\begin{array}{l}\text { - Third-party stories about } \\
\text { philanthropy efforts }\end{array}$ & \\
\hline & & $\begin{array}{l}\text { Employee volunteer } \\
\text { recognition program }\end{array}$ & - Disclose grants list & $\begin{array}{l}\text { Employee matching and } \\
\text { volunteer program }\end{array}$ & - Disclose grants list & \\
\hline & & - Disclose grants lists & & & & \\
\hline \multirow[t]{3}{*}{$\begin{array}{l}\text { Labor } \\
\text { Practices }\end{array}$} & $\begin{array}{l}\text { - Vendor code of } \\
\text { conduct }\end{array}$ & - Vendor code of conduct & - Vendor code of conduct & - Vendor code of conduct & - Vendor code of conduct & - Vendor code of conduct \\
\hline & $\begin{array}{l}\text { - Monitoring and } \\
\text { remediation }\end{array}$ & $\begin{array}{l}\text { - Monitoring and } \\
\text { remediation }\end{array}$ & $\begin{array}{l}\text { - Monitoring and } \\
\text { remediation }\end{array}$ & - Monitoring and remediation & - Monitoring and remediation & - Monitoring and remediation \\
\hline & $\begin{array}{l}\text { - Environmental } \\
\text { standards }\end{array}$ & - Environmental standards & - Case studies & $\begin{array}{l}\text { Supplier ownership } \\
\text { (new approach) }\end{array}$ & - Reporting on monitoring & - Disclose factory lists \\
\hline
\end{tabular}


Table 1 Summary and comparison of companies' website communications related to CSR, 2001-2009 (Continued)

\begin{tabular}{|c|c|c|c|c|c|c|}
\hline & \multirow[t]{8}{*}{$\begin{array}{l}\text { - Profiles of factory } \\
\text { assessors }\end{array}$} & \multirow{3}{*}{$\begin{array}{l}\text { Collaboration with } \\
\text { labor organization and } \\
\text { competitors }\end{array}$} & \multirow[t]{8}{*}{$\begin{array}{l}\text { - Collaboration with labor } \\
\text { organizations }\end{array}$} & $\begin{array}{l}\text { - Collaboration with labor } \\
\text { organizations }\end{array}$ & \multicolumn{2}{|l|}{ - Case studies } \\
\hline & & & & - Disclose factory lists & \multirow{2}{*}{$\begin{array}{l}\text { - Third-party stories about } \\
\text { efforts }\end{array}$} & \\
\hline & & & & - Disclose training & & \\
\hline & & $\begin{array}{l}\text { Profiles of factory } \\
\text { assessors }\end{array}$ & & regime for factory assessors & $\begin{array}{l}\text { Stakeholder criticisms and } \\
\text { company's responses }\end{array}$ & \\
\hline & & - Factory rating system & & - Influencing public policy & $\begin{array}{l}\text { - Student participation in } \\
\text { monitoring and reporting } \\
\text { results }\end{array}$ & \\
\hline & & - Case studies & & - Links to case studies & - Disclose factory lists & \\
\hline & & $\begin{array}{l}\text { - Disclose countries where } \\
\text { products are made }\end{array}$ & & & $\begin{array}{l}\text { - Collaboration with labor } \\
\text { organizations }\end{array}$ & \\
\hline & & $\begin{array}{l}\text { - External evaluations of } \\
\text { practices }\end{array}$ & & & & \\
\hline \multirow[t]{7}{*}{$\begin{array}{l}\text { Environmental } \\
\text { Practices }\end{array}$} & $\begin{array}{l}\text { Mention, but devote } \\
\text { little content to: }\end{array}$ & $\begin{array}{l}\text { Environmental policies } \\
\text { for factories }\end{array}$ & \multirow[t]{7}{*}{$\begin{array}{l}\text { - Mentioned but did not } \\
\text { elaborate }\end{array}$} & $\begin{array}{l}\text { - Environmental policies for } \\
\text { factories }\end{array}$ & $\begin{array}{l}\text { - Environmental policies for } \\
\text { factories }\end{array}$ & $\begin{array}{l}\text { - Environmental policies for } \\
\text { factories }\end{array}$ \\
\hline & - Production processes & $\begin{array}{l}\text { - Sustainable product } \\
\text { design }\end{array}$ & & - Sustainable product design & - Youth education program & - Sustainable building design \\
\hline & $\begin{array}{l}\text { - Energy and waste } \\
\text { reduction }\end{array}$ & $\begin{array}{l}\text { Energy and waste } \\
\text { reduction }\end{array}$ & & $\begin{array}{l}\text { - Third-party assessment of } \\
\text { environmental impacts }\end{array}$ & - Sustainable building design & - Sustainable product lifecycle \\
\hline & \multirow[t]{4}{*}{$\begin{array}{l}\text { - Sustainable building } \\
\text { design }\end{array}$} & $\begin{array}{l}\text { - Sustainable building } \\
\text { design }\end{array}$ & & - Grants to support sustainability & - Sustainable product lifecycle & - Alternative transportation \\
\hline & & $\begin{array}{l}\cdot \text { Alternative } \\
\text { transportation }\end{array}$ & & & - Energy and waste reduction & environmental organizations \\
\hline & & - Packaging & & & - Alternative transportation & - Influence public policy \\
\hline & & & & & - Industry collaboration & \\
\hline Diversity & - Employee diversity & - Employee diversity & - Employee diversity & - Employee diversity & $\begin{array}{l}\text { - Employee diversity and } \\
\text { internal Networks }\end{array}$ & $\begin{array}{l}\text { Employee diversity, } \\
\text { internal Networks and } \\
\text { additional programs }\end{array}$ \\
\hline
\end{tabular}


Table 1 Summary and comparison of companies' website communications related to CSR, 2001-2009 (Continued)

\begin{tabular}{|c|c|c|c|c|c|c|}
\hline & - Consumer diversity & - Consumer diversity & - Consumer diversity & - Supplier diversity & - Supplier diversity & - Supplier diversity \\
\hline & & $\begin{array}{l}\text { - Grants to underrepresented } \\
\text { groups }\end{array}$ & & - Consumer diversity & - Consumer diversity & - Consumer diversity \\
\hline \multirow{5}{*}{$\begin{array}{l}\text { Account- } \\
\text { ability }\end{array}$} & - None present & - CSR reports & - Case studies & - Case studies & - Case studies & - CSR reports \\
\hline & & - Case studies & - Reporting in content & - Reporting in content & - Reporting in content & - Case studies \\
\hline & & - Reporting in content & & - Disclose grants lists & - Disclose grants lists & - Reporting in content \\
\hline & & - External evaluations & & - Disclose factory lists & - Disclose factory lists & - Disclose grants lists \\
\hline & & - Disclose grants lists & & - External evaluations & - External evaluations & - Disclose factory lists \\
\hline \multirow[t]{2}{*}{ Recogni-tion } & - None present & - Recognitions list & - Recognitions list & - Recognitions list & $\begin{array}{l}\cdot \text { Recognitions list } \\
\text { throughout content }\end{array}$ & - Recognitions list \\
\hline & & & $\begin{array}{l}\text { - Recognitions throughout } \\
\text { content }\end{array}$ & $\begin{array}{l}\text { - Recognitions throughout } \\
\text { content }\end{array}$ & $\begin{array}{l}\text { - Stakeholder testimonials } \\
\text { - Third-party news stories }\end{array}$ & $\begin{array}{l}\text { - Recognitions } \\
\text { throughout content }\end{array}$ \\
\hline
\end{tabular}


pattern, taking a more concise approach to its reporting in 2009. Several shifts in the content of CSR reporting also were observed. On the 2001 websites, all three companies gave considerable emphasis to philanthropic endeavors and labor practices. Although communications relative to these themes continued in 2009, at this time, the companies had expanded their focus to include greater emphasis upon the motivations for engaging in CSR and the theme of environmental practices.

Further, whereas in 2001, the companies were somewhat reactionary in their reporting about CSR policies and practices, by 2009, their communications reflected a more proactive and planned approach to socially responsible decision-making. For example, in 2001, Nike's website communications about labor practices appeared to be driven by stakeholder pressures; in a letter responding to the protests from the United Students Against Sweatshops, Nike wrote, "Admittedly, the public attention focused our efforts and helped us act sooner and bolder than we had before" (An Open, 2000, para. 9). By 2009, however, all three companies had adopted a more proactive approach to CSR reporting, often addressing their progress and performance on CSR initiatives, suggesting that taking such an approach may be a growing norm within the apparel industry (DiMaggio \& Powell, 1983; Meyer \& Rowan, 1977; Scott, 2004), particularly among CSR "standard bearers" such as those examined in this analysis (cf., Ählström, 2010).

Analyses also suggested that Gap, Levi Strauss, and Nike were engaging in more solution-oriented approaches to CSR in 2009 as compared to 2001. When reporting on labor practices in 2009, both Levi Strauss and Nike presented information about how they were searching for ways to improve labor practices that went beyond labor codes of conduct, monitoring, and remediation. Levi Strauss described an approach called Supplier Ownership in which the company worked to empower suppliers and to increase their involvement in improving labor conditions in their own factories. Nike also acknowledged that monitoring and remediation would not fix problems with labor conditions in the industry and stated that the company planned to "[get] to the root of the problem" ("Workers and Factories", n.d., para. 4) by examining how its product development process contributed to non-ideal working conditions.

The shifts toward more proactive postures by the companies in 2009 may have been related to their increased levels of experience with implementing CSR initiatives. Today, Gap, Levis Strauss, and Nike often are cited as leaders in CSR practices, but based upon their CSR reporting in 2001, it was clear that the companies were still devising strategies for simultaneously meeting business growth goals and the expectations of a variety of stakeholders.

\section{Conclusions and implications}

The apparel companies examined in this study employed CSR reporting on their corporate websites to construct specific impressions about their institutional values as well as the motivations that drove them to embrace a socially responsible approach to decision-making. Findings yield insights into both the actual CSR practices of the companies examined as well as how the companies wished their stakeholders to perceive them relative to their CSR initiatives (cf., Basil \& Erlandson, 2008). Findings also provide understanding of the ethical concerns unique to the apparel industry - an industry that poses a high risk for negative social and environmental impacts due to the nature of its global supply chain - during the years 2001 and 2009. 
For the most part, the companies used their websites to frame their business decisions as responsible or as "good deeds" enacted in support of people, planet, and profit. In some instances, however, the companies also utilized their websites as a vehicle for clarifying or justifying business activities that stakeholders might perceive as "missteps" in the companies' records on CSR. As such, findings provide support for institutional theory and its tenet that organizations frame their disclosures of information so as to direct attention toward positive behaviors and to minimize the impact of negative information (Elsbach \& Sutton, 1992; Meyer \& Rowan, 1977). Further, findings demonstrate that the behaviors of apparel companies are shaped by all three elements of institutional theory. For example, on its website, Nike reported that their engagement in CSR initiatives was, to some degree, motivated by regulatory bodies (i.e., governments). And, analyses provide evidence that both Gap and Levi Strauss were influenced by normative elements of institutions with respect to their efforts to improve labor practices, whereas Nike's efforts to identify shared meanings of "diversity" among employees reflect the importance of cultural-cognitive elements in institutional decision-making.

Analyses also revealed that, in both 2001 and 2009, the companies' considered themselves to be accountable to multiple stakeholders. Communications referenced a wide array of stakeholder groups, including fringe groups such as the media, minorities, nongovernmental organizations, students, and sponsored athletes. Thus, findings provide support for the application of a stakeholder orientation in the apparel industry in that CSR reporting addressed the companies' engagement of diverse stakeholders in the implementation of their various CSR policies and practices (i.e., the organizational decision-making process).

This study offers a number of implications for both apparel companies and researchers. For instance, the ethical issues to which apparel companies assign the most importance appear to have shifted in recent years to reflect growing global concern for the natural environment. That is, whereas 2001 website communications emphasized labor policies and practices, 2009 communications focused more intensely upon environmental efforts. As such, findings are consistent with the work of Islam and Deegan (2010), who observed increased disclosures on the topic of environmental issues by the apparel retailer, H\&M, over a 19-year period (1987-2005). This shift in CSR reporting parallels concerns in the industry, reflecting the pervasive labor abuses in the global apparel industry during the 1990s - which received a great deal of media attention and which were addressed through the Clinton administration's No Sweat Initiative - and the more recent emphasis upon achieving sustainability throughout the product lifecycle. For example, in 2009 the Sustainable Apparel Coalition was formed with the goal of developing an index to assess the environmental impact of apparel products (Gunther, 2012). The outcome of this effort was the introduction of the Higg Index 2.0 in 2013, which is used to measure environmental performance of apparel and footwear products across the supply chain at the brand, product, and facility levels (Sustainable Apparel Coalition, n.d.). Thus, to develop and implement CSR initiatives that will resonate with stakeholders and to meet their expectations relative to socially responsible business practices, apparel companies should stay apprised of current industry issues and communicate their proactive commitment to addressing these issues to varied stakeholder groups. Additionally, given that the companies differed in the emphasis given to varied aspects of CSR within their CSR reporting - and that these differences seemed to reflect unique stakeholder interests - apparel companies would be well- 
served to identify which aspects of CSR are most important to salient stakeholders and to tailor their communications accordingly. Another implication lies in what the companies did not emphasize within their CRS reporting, such as the topic of advertising. For instance, in 2005, Nike launched a campaign designed to encourage women to value their bodies for their physical capabilities rather than for their appearances. The company did not, however, mention its efforts to use advertising messages to help women overcome body image issues on its 2009 website, even though featuring such information could positively affect stakeholder evaluations of Nike.

Although the present analysis provides understanding of how apparel companies used their website communications to frame their business activities and their engagement in CSR during 2001 and 2009, it does not afford understanding of why the companies chose to include or exclude specific content in their CSR reporting during this period, nor does it reveal if and how communications about CSR related to their actual CSR practices at that time. Thus, it would be valuable to explore these topics by analyzing the perspectives of company executives and/or documents that would provide evidence of the companies' actual CSR records (e.g., audits, third party reports, news articles). Additionally, it would be interesting to compare corporate websites developed to promote goods to consumers in diverse countries/cultures and to note if and how the CSR reporting on such websites differs. Because the data for the present study reflect CSR practices from 2001 and 2009, it is likely that they may not fully reflect the scope of CSR issues and actions that exist within the apparel industry today. Thus, it would be valuable to collect data from current websites to ascertain how CSR reporting continues to evolve. Finally, researchers may extend examinations of the content of CSR communications by analyzing the effectiveness of such communications among varied stakeholder groups and/or specific aspects of these communications (e.g., channel, message appeal) that may make them more or less effective.

Competing interests

The authors declare that they have no competing interests.

Received: 27 March 2014 Accepted: 7 August 2014

Published online: 09 October 2014

References

A glance at Nike's Challenges And Successes Of Corporate responsibility Initiatives: Age Limits. (n.d.). Retrieved from http://web.archive.org/web/20010604084127/nikebiz.com/labor/kudong_rot.shtml.

Ählström, J. (2010). Corporate response to CSO criticism: Decoupling the corporate responsibility discourse from business practice. Corp Soc Responsib Environ Manag, 17(2), 73-80.

An Open Letter Response To USAS Regarding Their National Protest Of Nike Through August 16, 2000. (2000). Retrieved from http://web.archive.org/web/20010111070400/nikebiz.com/labor/usas_let.shtml.

At Gap Inc. (n.d.). At Gap Inc. (n.d.). Retrieved from http://www.gapinc.com/public/SocialResponsibility/socialres.shtml.

Basil, DZ, \& Erlandson, J. (2008). Corporate social responsibility website representations: A longitudinal study of internal and external self-presentations. J Mark Commun, 14(2), 125-137.

Bhattacharya, CB, \& Sen, S. (2004). Doing better at doing good: When, why, and how consumers respond to corporate social initiatives. Calif Manag Rev, 47(1), 9-24.

Brown, MS, \& Wilmanns, E. (1997). Quick and dirty environmental analyses for garments: What do we need to know? J Sustain Prod Des, 1(1), 28-35.

Business operations. Corporate Social Responsibility. (n.d.). Retrieved from http://web.archive.org/web/20010411233813/ www.levistrauss.com/index_about.html.

Calabro, S. (2003). Poll says people base trust on media over advertising. PR Week, 23, 5.

Capriotti, P, \& Moreno, A. (2007). Communicating corporate responsibility through corporate web sites in Spain. Corp Commun Int J, 12(3), 221-237.

Caring For The Environment. (n.d.). Retrieved from http://www.gapinc.com/public/SocialResponsibility/sr_environment.shtml.

Carroll, AB. (1991). The pyramid of corporate social responsibility: Toward the moral management of organizational stakeholders. Business Horizons, 34(4), 39-48.

Chen, H, \& Burns, LD. (2006). Environmental analysis of textile products. Cloth Text Res J, 24(3), 248-261.

Clarkson, MBE. (1995). A stakeholder framework for analyzing and evaluating corporate social performance. Acad Manag Rev, 20(1), 92-117.

Community Investment. (n.d.). Retrieved from http://www.gapinc.com/public/SocialResponsibility/sr_community.shtml. 
Consumers Worldwide Expect Businesses To Achieve Social As Well As Economic Goals New Study Pinpoint. (1999). Retrieved from http://www.ipsos-mori.com/content/consumers-worldwide-expect-businesses-to-achieve-s.ashx.

Corbin, J, \& Strauss, A. (2008). Basics Of Qualitative Research: Grounded Theory Procedures And Techniques. Thousand Oaks, CA: Sage.

Dawkins, J. (2004). Corporate responsibility: The communication challenge. J Commun Manag, 9(2), 108-119.

Dawkins, J, \& Lewis, S. (2003). CSR in stakeholder expectations: And their implications for company strategy. J Bus Ethics, 44(2-3), 185-193.

Dickson, MA, \& Eckman, M. (2006). Social responsibility: The concept as defined by apparel and textile scholars. Cloth Text Res J, 24(3), 178-191.

Dickson, MA, Loker, S, \& Eckman, M. (2008). Social responsibility in the global apparel industry. New York, NY: Fairchild Books.

DiMaggio, PJ, \& Powell, WW. (1983). The iron cage revisited: Institutional isomorphism and collective reality in organizational fields. Am Sociol Rev, 48(2), 147-166.

Diversity \& inclusion at Levi Strauss \& Co. (n.d.). Retrieved from http://levistrauss.com/Citizenship/Diversity.aspx.

Donaldson, T, \& Preston, LE. (1995). The stakeholder theory of the corporation: Concepts, evidence, and implication. Acad Manag Rev, 20(1), 65-91.

Elsbach, KD, \& Sutton, Rl. (1992). Acquiring organizational legitimacy through illegitimate actions: A marriage of institutional and impression management theories. Acad Mange J, 35(4), 699-738.

Emmelhainz, MA, \& Adams, RJ. (1999). The apparel industry response to "sweatshop" concerns: A review and analysis of codes of conduct. J Supply Chain Manage, 35(3), 51-57.

Ethisphere Magazine mission statement. (n.d.). Retrieved from http://ethisphere.com/about-ethisphere/.

External evaluations. (n.d.). Retrieved from http://www.gapinc.com/public/SocialResponsibility/sr_fac_partner_ee.shtml.

Farache, F, \& Perks, KJ. (2010). CSR advertisements: A legitimacy tool? Corp Commun Int J, 15(3), 235-248.

Fraser, BW. (2005). Corporate social responsibility. Intern Audit, 62(1), 42-47.

Freeman, B. (2006). Substance sells: Aligning corporate reputation and corporate responsibility. Public Relat Q, 5(1), 12-19.

Freeman, R. (1984). Strategic management: A stakeholder approach. Boston, MA: Pitman.

Frequently asked questions: Social responsibility. (n.d.). Retrieved from http://www.gapinc.com/public/SocialResponsibility/ sr_faq.shtml.

Giving programs. (n.d.). Retrieved from http://web.archive.org/web/20010411214044/ www.levistrauss.com/ index_community.html.

Global compliance team profiles. (n.d.). Retrieved from http:/www.gapinc.com/public/SocialResponsibility/ sr_fac_team_kapil.shtml.

Gray, R. (2008). Social and environmental accounting and reporting: From ridicule? From hope to hubris? - A personal review of the field. Issues Social Environ Account, 2(1), 3-18.

Greider, W. (1994). The global sweatshop. Rolling Stone, p. 685.

Griffin, JJ, \& Mahon, JF. (1997). The corporate social performance and corporate financial performance debate: Twenty-five years of incomparable research. Business Soc, 36, 5-31.

Gunther, M. (2012). Inside the Sustainable Apparel Coalition. Retrieved from http://www.marcgunther.com/inside-thesustainable-apparel-coalition/.

Halal, WE. (2001). The collaborative enterprise: A stakeholder model uniting profitability and responsibility. J Corporate Citizenship, 2, 27-42

Hart, SL, \& Sharma, S. (2004). Engaging fringe stakeholders for competitive imagination. Acad Manag Exec, 18(1), 7-18.

Holder-Webb, L, Cohen, JR, Nath, L, \& Wood, D. (2009). The supply of corporate social responsibility disclosures among U.S. firms. J Bus Ethics, 84(4), 497-527.

Islam, MA, \& Deegan, C. (2010). Media pressures and corporate disclosure of social responsibility performance information: A study of two global clothing and sports retail companies. Account Bus Res, 40(2), 131-148.

Islam, MA, \& McPhail, K. (2011). Regulating for corporate human rights abuses: The emergence of corporate reporting on the ILO's human rights standards within the global garment manufacturing and retail industry. Crit Perspect Account, 22(8), 790-810

Iwanow, H, McEachern, MG, \& Jeffrey, A. (2005). The influence of ethical trading policies on consumer apparel purchase decisions: A focus on The Gap Inc. Int J Retail Distrib Manag, 23(5), 371-387.

Kavitha, W, \& Anita, P. (2011). Disclosures about CSR practices: A literature review. IUP J Corporate Govern, 10(1), 45-55.

Kent, ML, Taylor, M, \& White, WJ. (2003). The relationship between web site design and organizational responsiveness to stakeholders. Public Relat Rev, 29(2), 63-77.

Kolk, A, \& van Tulder, R. (2002). The effectiveness of self-regulation: Corporate codes of conduct and child labour. Eur Manag J, 20(3), 260-271.

Labor: Frequently asked questions. (n.d.). Retrieved from http://web.archive.org/web/20010417022452/nikebiz.com/labor/faq.shtml. Laudal, T. (2010). An attempt to determine the CSR potential of the international clothing business. J Bus Ethics, 96(1), 63-77.

Maignan, I, \& Ralston, DA. (2002). Corporate social responsibility in Europe and the U.S.: Insights from businesses' self-presentations. J Int Bus Stud, 33(3), 497-514.

Meyer, JW, \& Rowan, B. (1977). Institutionalized organizations: Formal structure as myth and ceremony. Am J Sociol, 83(2), 340-363.

Mission and overview of the Nike Foundation. (n.d.). Retrieved from http://web.archive.org/web/20010331093018/nikebiz. com/community/miss_obj.shtml.

Nike helps fight anti-gay legislation. (2000b). Retrieved from http://web.archive.org/web/20010331101029/nikebiz.com/ community/pringca.shtml.

Nike responsibility FY05-06 CR report (n.d.). Retrieved from http://www.nikebiz.com/responsibility/.

Nike talks trash and the environment with new shoe: Steve Nash debuts recycled materials shoe. (n.d.). Retrieved from http://www.nikebiz.com/responsibility/considered_design/features/nike_talks_trash.html.

Our corporate values. (n.d.). Retrieved from http://levistrauss.com/Citizenship/.

Our supplier diversity initiative. (n.d.). Retrieved from http://web.archive.org/web/20010129001900/nikebiz.com/diversity/ supplier4.shtml. 
Parloff, R. (2002). Can we talk? Fortune, 146(4). Retrieved from http://money.cnn.com/magazines/fortune/ fortune_archive/2002/09/02/327912/.

Pollach, I. (2005). Corporate self-presentation on the WWW: Strategies for enhancing usability, credibility, and utility. Corp Commun Int J, 10(4), 285-301.

Recognition. (n.d.). Retrieved from http://www.gapinc.com/public/About/abt_recognition.shtml.

Saipan. (n.d.). Retrieved from http://web.archive.org/web/20010107213400/www.gapinc.com/about/global_manuf/ code_overview/saipan.htm.

Scott, WR. (2004). Institutional theory. In G Ritzer (Ed.), Encyclopedia of social theory (pp. 408-414). Thousand Oaks, CA: Sage.

Scott, WR. (2005). Institutional theory: Contributing to a theoretical research program. In KG Smith \& MA Hitt (Eds.), Great minds in management: The process of theory development (pp. 460-485). Oxford UK: Oxford University Press.

Sen, S, \& Bhattacharya, CB. (2001). Does doing good always lead to doing better? Consumer reactions to corporate social responsibility. J Mark Res, 38(2), 225-243.

Snider, J, Hill, RP, \& Martin, D. (2003). Corporate social responsibility in the $21^{\text {st }}$ century: A view from the world's most successful firms. J Bus Ethics, 48(2), 175-187.

Steve Nash and Nike turn garbage into "Trash Talk. (2008). Retrieved from http://www.nikebiz.com/media/pr/2008/02/ 13_Nash.html.

Sustainable Apparel Coalition. (n.d.). Overview. Retrieved from http://www.apparelcoalition.org/higgindex.

Vanhamme, J, \& Grobben, B. (2009). Too good to be true! The effectiveness of CSR history in countering negative publicity. J Bus Ethics, 85(supplement 2), 273-283.

Web collaborations. (n.d.). Retrieved from http://www.archive.org/web/collaborations.php.

Welford, R, \& Frost, S. (2006). Corporate social responsibility in Asian supply chains. Corp Soc Responsib Environ Manag, 13(3), 166-176.

Where we work: Building smart. (n.d.). Retrieved from http://web.archive.org/web/20010811071041/www.nikebiz.com/ environ/operations.shtml.

Women in the developing world. (n.d.). Retrieved from http://www.gapinc.com/public/SocialResponsibility/ sr_com_target_women.shtml.

Workers \& factories: Improving conditions in our contract factories. (n.d.). Retrieved from http://www.nikebiz.com/ responsibility/workers_and_factories.html.

Young, S, \& Marais, M. (2012). A multi-level perspective of CRS reporting: The implications of national institutions and industry risk characteristics. Corporate Govern Int Rev, 20(5), 432-450.

Zadek, S. (2004). The path to corporate responsibility. Harv Bus Rev, 82(12), 125-132.

doi:10.1186/s40691-014-0011-8

Cite this article as: Gaskill-Fox et al.: CSR reporting on apparel companies' websites: framing good deeds and clarifying missteps. Fashion and Textiles 2014 1:11.

\section{Submit your manuscript to a SpringerOpen ${ }^{\circ}$ journal and benefit from:}

- Convenient online submission

- Rigorous peer review

- Immediate publication on acceptance

- Open access: articles freely available online

- High visibility within the field

- Retaining the copyright to your article

Submit your next manuscript at $\boldsymbol{\nabla}$ springeropen.com 